\title{
Oral Administration of Alginate from A Tropical Brown Seaweed, Sargassum sp. to Enhance Non-Spesific Defense in Walking Catfish (Clarias sp.)
}

\author{
Alim Isnansetyo, Husni Mubarok Irpani, Tyas Ayu Wulansari and Noer Kasanah \\ Department of Fisheries. Faculty of Agriculture. Gadjah Mada University. Jl. Flora. Bulaksumur. Yogyakarta. 55281 \\ Indonesia
}

\begin{abstract}
Alim Isnansetyo, Husni Mubarok Irpani, Tyas Ayu Wulansari, and Noer Kasanah. 2014. Oral Administration of Alginate from A Tropical Brown Seaweed, Sargassum sp. to Enhance Non-Spesific Defense in Walking Catfish (Clarias sp.). Aquacultura Indonesiana, 15 (2) : 14-20. Alginate that is usually extracted from brown seaweeds, is a bioactive substance with immunomodulator activity. The purpose of this research was to evaluate the effect of oral administration of alginate on the non-specific immune system of walking catfish (Clarias sp.). An experiment was conducted in a Completely Randomized Design with five treatments in triplicates. Alginate was supplemented in feed at doses of 0 (control treatment), 2, 4, 6, and $8 \mathrm{~g} / \mathrm{kg}$ of feed. The walking catfish was fed twice daily at feeding rate of $5 \%$. Non-specific defense parameters evaluated were Nitroblue Tetrazolium (NBT) activity, phagocytic activity (PA), phagocytic index (PI), leukocyte differentiation, hematocrit and leucocrit. The parameters were observed prior to be treated, $5^{\text {th }}, 10^{\text {th }}$ and $15^{\text {th }}$ days after treatments. Oral administration of alginate at $4 \mathrm{~g} / \mathrm{kg}$ of feed increased NBT and PA activities significantly $(P<0.05)$ in 5 days, while alginate at a dose of $6 \mathrm{~g} / \mathrm{kg}$ increased NBT activity and monocyte percentage significantly $(P<0.05)$ in 5 days. These results suggested that oral administration of alginate at $4 \mathrm{~g} / \mathrm{kg}$ effectively increased non-specific immune system of walking catfish.
\end{abstract}

Keywords: Alginate; Clarias sp.; Non-specific immunity; Sargassum sp.

\section{Introduction}

Walking catfish (Clarias sp.) is an important economical species in Indonesian fresh water aquaculture. The culture production of this species in Indonesia has increased constantly. In 2009 and 2010, the production reached 137,808 and 236,764 ton, respectively. Significant increase of the production has also occurred in 2011 reaching 330,687 ton (Ministry of Fisheries and Marine Affair, 2012). Increase in the walking catfish production is achieved by intensifying culture and also improving the culture area especially through the development of small scale aquaculture.

One of a crucial problem in intensive aquaculture is the outbreak of fish diseases caused by infective agents such as bacteria, virus and parasites. Intensive walking cat fish culture has high risk of diseases outbreak because of high density and high feeding rate which may decrease the water quality. The use of immunostimulant is one of environmental friendly prophylactic method to control disease in aquaculture. Immunostimulant mainly improves the non-specific immune response of fish against infective agents.

Seaweed is lower plant which has already known as the resource of bioactive primary and secondary metabolites. Alginate as the component of cell wall structure in brown seaweeds is known to be a substance with immunomodulator activity. This polysaccharide improves the immune system in Lithopenaeus vannamei (Yeh et al., 2005). However, the immunomodulation effect of alginate has not been evaluated yet in walking catfish.

One of the brown seaweeds grown well and easy to be harvested in tropical area including Indonesia is Sargassum sp. Sargassum is the genus of brown seaweed which has highest biodiversity in Indonesia. Off 28 species of brown seaweed identified in Indonesia, 14 species are the member of the genus Sargassum (Rachmat, 1999). This plentiful seaweed might be utilized as the source of immunostimulant to create the environmental friendly aquaculture system. The purpose of this research was to evaluate the effect of alginate on the non-specific immune response by determining fish hematologic parameters.

\section{Materials and Methods}

\section{Sampling of Sargassum sp.}

Sargassum sp. sample was collected from the coastal of Gunung kidul, Yogyakarta, Indonesia. The sample was packed and 
transported to the laboratory by using a cool box, and air dried without direct sun light.

\section{Alginate Extraction}

Seaweeds were cut in c.a. $0.5 \mathrm{~cm}^{2}$ and macerated in $0.1 \mathrm{~N} \mathrm{HCl}$ for 24 hours at room temperature, then filtered. The retainage was macerated again in $0.2 \mathrm{~N} \mathrm{HCl}$ at $70^{\circ} \mathrm{C}$ for 2 hours. Filtrate was filtered through Watman paper number 40 and then combined. The filtrate was evaporated by rotary evaporator at $60^{\circ} \mathrm{C}$. After evaporation, the extract was neutralized with $\mathrm{NaOH}$ and precipitated with cold $95 \%$ ethanol. After centrifugation at 3,500 rpm for $15 \mathrm{~min}$, obtained pellet was solubilized in aquadest ( $\mathrm{pH} 2$ ). Alginate was precipitated with $\mathrm{CaCl}_{2}$ and centrifugation at 3,500 rpm for $15 \mathrm{~min}$. Obtained alginate was dried at $60^{\circ} \mathrm{C}$ and stored at $4^{\circ} \mathrm{C}$ until used.

\section{Alginate Supplementation in Feed}

Alginate was solubilized in water and added with $3 \%$ of white chicken egg. Alginate suspension was supplemented to a grinded commercial feed (D0) and gradually added with warm water $\left( \pm 50^{\circ} \mathrm{C}\right)$ while mixing. Five doses of alginate were added namely 0 (control diet), 2, 4, 6 , and $8 \mathrm{~g} / \mathrm{kg}$ of feed. Then the feed was pelleted and dried at $40^{\circ} \mathrm{C}$ for $8 \mathrm{~h}$. The dried pellet was packed in plastic bag and stored in refrigerator until used.

\section{Feeding Trial}

This experiment used a completely randomized design in triplicates. Five group treatments of walking catfish $( \pm 100 \mathrm{~g})$ were fed with the above feed. The fish was reared in fiberglass tank $\left(50 \times 50 \times 60 \mathrm{~cm}^{3}\right)$ at a density of 3 fishes/tank, and fed twice daily at $5 \%$ of feeding rate. Blood sampling was carried out 0 day (before feeding experiment started), 5, 10 and 15 days after feeding experiment started. Blood sample $(0.5 \mathrm{~mL} / \mathrm{fish})$ was withdrawn from arteri caudalis using $1 \mathrm{~mL}$ syringe with $10 \%$ EDTA as an anti-coagulant. Before blood sampling, the fish were anesthetized with clove oil at $0.05 \%(\mathrm{~V} / \mathrm{V})$. The blood was transferred to microtube and evaluated for non-specific immune system using the method of Anderson and Siwicky (1994) with modification (Isnansetyo, 2006).

\section{Nitroblue Tetrazolium NBT Test}

One hundred microliter of fish blood was transferred to a microtube and added with the same volume of $0.2 \%$ NBT (Sigma) in $0.85 \%$ $\mathrm{NaCl}$. After incubation at room temperature for $30 \mathrm{~min}, 50 \mu \mathrm{L}$ sample was transferred to a glass tube and added with $1 \mathrm{~mL}$ of $\mathrm{N}-\mathrm{N}$ dimethylformamide. Then centrifugation was carried out at $3,000 \mathrm{~g}$ for $5 \mathrm{~min}$ to obtain supernatant. The absorbance of the supernatant was measured with a spectrophotometer at $540 \mathrm{~nm}$.

\section{Leucocrit and Hematocrit Test}

The blood samples were filled to microhematocrit capillary tubes, and centrifuged at $1,500 \mathrm{~g}$ for $5 \mathrm{~min}$ to separate red blood cells, white blood cells and plasma. The leucocrit and hematocrit observed by measuring the length of red and white blood in the capillaries. Leucocrit and hematocrit then were calculated in percentage.

\section{Phagocytic Activity (PA) and Phagocytic Index (PI)}

Phagocyitic activity test was carried out based on the method of Anderson and Siwicki (1994). Fifty microliter of white blood cells was transferred to 96 wells microplate, and added with the same volume of formalin-killed Staphylococcus aureus. After incubation at $30^{\circ} \mathrm{C}$ for $30 \mathrm{~min}$, each sample was smeared on object glass and stained with $10 \%$ Giemsa. The phagocytic activity was determined by microscopic observation at 1,000 $\mathrm{x}$ magnification Phagocytic activity (PA) and phagocytic index (PI) were calculated from 100 phagocytes per slide. PA was calculated using the equation published previously. PI was determined from 100 phagocytes indicating the overage of bacterial cells ingested by a phagocyte.

\section{Differentiation of Leukocyte}

Observation of leukocyte differentiation was conducted by smearing $5 \mu \mathrm{L}$ sample from microplate on an object glass. After air drying, the samples were fixed with $95 \%$ ethanol for 5 min. Staining was conducted with $10 \%$ Giemsa for $15 \mathrm{~min}$. After washing with aquadest and air drying, monocyte, lymphocyte, neutrophile dan eosinophile were observed under a microscope. 


\section{Data Analysis}

Data of are presented as mean \pm standard deviation of three replicates. If necessary, the data were normalized before one-way analysis of variance (ANOVA). When the ANOVA analysis resulted significant difference among the treatment groups, a Dunnet test was conducted to examine the difference among treatments and means. The statistical analysis was conducted by using SAS 9.1.3. program (SAS Institute. Cary. NC. USA).

\section{Results and Discussion}

\section{Results}

Nitroblue Tetrazolium (NBT) Activity

NBT activity of walking catfish before treatment ranged from 0.4611 to 0.629 . while at $5^{\text {th }}$ day after feeding trial the activity ranged from 0.428 to 0.638 . The activities at $10^{\text {th }}$ and $15^{\text {th }}$ day after feeding trial were in the range of $0.425-0.492$ and $0.428-0.469$, respectively. Supplementation of alginate in feed increased significantly the NBT activity $(P<0.05)$ at $5^{\text {th }}$ day after feeding trial.
Dunnet test indicated that alginate supplementation at doses of 4 and $6 \mathrm{~g} / \mathrm{kg}$ of feed effectively increased NBT activity (Table 1).

Phagocytic Activity (PA)

Analysis of variance indicated that the alginate supplementation significantly increased the phagocytic activity of walking cat fish $(P<0.05)$ at $5^{\text {th }}$ day after feeding trial started. Furthermore, Dunnet test suggested that an alginate dose at $4 \mathrm{~g} / \mathrm{kg}$ of feed effectively increased the phagocytic activity. However, alginate did not affect the phagocytic activity at $10^{\text {th }}$ and $5^{\text {th }}$ days after feeding trial (Table 2).

Phagocytic Index

Oral administration of alginate did not affect the phagocytic index (PI) of catfish macrophage $(P>0.05)$. Before treatment the PI ranged from 16.70 to $20.95 \%$. The PIs at $5^{\text {th }}, 10^{\text {th }}$ and $15^{\text {th }}$ days post treatment did not significantly change PI that were in the range of $17.85-29.04 \%$, $16.66-26.66 \%$ and $18.09-22.38 \%$, respectively (Table 3).

Table 1. NBT activity of walking catfish blood before and after feeding with various doses of alginate

\begin{tabular}{lcccc}
\hline \multirow{2}{*}{ Treatment } & 0 & 5 & 10 & 15 \\
\cline { 2 - 5 } & $0.461 \pm 0.125$ & $0.428 \pm 0.049$ & $0.425 \pm 0.093$ & $0.428 \pm 0.069$ \\
P1 $(0 \mathrm{~g} / \mathrm{kg}$, Control $)$ & $0.496 \pm 0.076$ & $0.434 \pm 0.081$ & $0.492 \pm 0.002$ & $0.469 \pm 0.067$ \\
P2 $(2 \mathrm{~g} / \mathrm{kg})$ & $0.566 \pm 0.046$ & $0.638 \pm 0.036^{*}$ & $0.461 \pm 0.016$ & $0.468 \pm 0.014$ \\
P3 $(4 \mathrm{~g} / \mathrm{kg})$ & $0.629 \pm 0.118$ & $0.632 \pm 0.138^{*}$ & $0.436 \pm 0.081$ & $0.449 \pm 0.035$ \\
P4 $(6 \mathrm{~g} / \mathrm{kg})$ & $0.523 \pm 0.096$ & $0.453 \pm 0.031$ & $0.437 \pm 0.042$ & $0.433 \pm 0.066$ \\
P5 $(8 \mathrm{~g} / \mathrm{kg})$ &
\end{tabular}

Asterisk (*) indicates the significant different with control treatment

Table 2. Phagocytic activity of walking catfish macrophage before and after feeding with various doses of alginate

\begin{tabular}{lllll}
\hline \multirow{2}{*}{ Treatment } & \multicolumn{4}{c}{ Day of sampling } \\
\cline { 2 - 5 } & \multicolumn{1}{c}{0} & \multicolumn{4}{c}{10} & 15 \\
\hline P1 $(0 \mathrm{~g} / \mathrm{kg} \cdot$ Control $)$ & $18.07 \pm 1.67$ & $17.89 \pm 1.93$ & $16.66 \pm 4.36$ & $16.19 \pm 2.18$ \\
P2 $(2 \mathrm{~g} / \mathrm{kg})$ & $19.71 \pm 7.73$ & $23.33 \pm 2.97$ & $21.42 \pm 4.28$ & $19.52 \pm 1.65$ \\
P3 $(4 \mathrm{~g} / \mathrm{kg})$ & $21.42 \pm 2.47$ & $25.23 \pm 2.97 *$ & $22.38 \pm 2.97$ & $20.95 \pm 2.18$ \\
P4 $(6 \mathrm{~g} / \mathrm{kg})$ & $19.04 \pm 2.18$ & $19.52 \pm 2.18$ & $17.14 \pm 2.85$ & $19.04 \pm 4.36$ \\
P5 $(8 \mathrm{~g} / \mathrm{kg})$ & $18.31 \pm 2.97$ & $18.57 \pm 2.47$ & $17.61 \pm 2.18$ & $16.66 \pm 2.18$ \\
\hline
\end{tabular}

Asterisk (*) indicates the significant different with control treatment

Table 3. Phagocytic index of walking catfish macrophage before and after feeding with various doses of alginate

\begin{tabular}{lllll}
\hline \multirow{2}{*}{ Treatment } & \multicolumn{4}{c}{ Day of sampling } \\
\cline { 2 - 5 } & \multicolumn{1}{c}{0} & \multicolumn{1}{c}{5} & 10 & 15 \\
\hline P1 $(0 \mathrm{~g} / \mathrm{kg}$. Control $)$ & $16.70 \pm 7.24$ & $17.85 \pm 3.11$ & $16.66 \pm 2.18$ & $18.09 \pm 3.59$ \\
P2 $(2 \mathrm{~g} / \mathrm{kg})$ & $18.46 \pm 3.96$ & $28.57 \pm 11.69$ & $25.71 \pm 5.15$ & $22.38 \pm 4.36$ \\
P3 $(4 \mathrm{~g} / \mathrm{kg})$ & $17.14 \pm 4.28$ & $29.04 \pm 2.18$ & $26.66 \pm 2.97$ & $22.85 \pm 2.85$ \\
P4 $(6 \mathrm{~g} / \mathrm{kg})$ & $20.95 \pm 2.97$ & $24.76 \pm 2.97$ & $20.47 \pm 3.29$ & $21.90 \pm 2.18$ \\
P5 $(8 \mathrm{~g} / \mathrm{kg})$ & $19.92 \pm 2.98$ & $20.47 \pm 4.36$ & $19.52 \pm 1.65$ & $18.57 \pm 2.85$ \\
\hline
\end{tabular}


Leukocyte Differentiation

Monocyte Percentage

Result of variance analysis indicated that oral administration of alginate affected significantly the percentage of monocyte of walking catfish $(P<0.05)$. An alginate dose at $6 \mathrm{~g} / \mathrm{kg}$ of feed significantly increased the monocyte percentage. However, the percentage was not significantly different when the blood sampling were carried out at $10^{\text {th }}$ and $15^{\text {th }}$ day after starting the treatment (Table 4).

Lymphocyte Percentage

Generally, lymphocyte percentages of walking catfish fluctuated during experiment. Analysis of variance indicated that lymphocyte percentage was not significantly affected by the oral administration of alginate $(P>0.05)$ (Table 5).

Trombocyte Percentage

Results of variance analysis indicated that trombocyte percentage was not insignificant different among the treatment implying that oral administration of alginate did not affect the trombocyte percentage $(P>0.05)$ (Table 6$)$.
Neutrophil Percentage

Neutrophil percentage of walking catfish before treatment ranged from 11.38 to $13.07 \%$. The percentages were insignificant different among treatment $(P>0.05)$ at $5^{\text {th }}, 10^{\text {th }}$ and $15^{\text {th }}$ days after treatment, which were in the range of $12.07-13.58 \%, 12.05-13.41 \%$ and $10.61-14.89 \%$, respectively (Table 7).

\section{Eosinophil Percentage}

Oral administration of alginate did not affect the eosinophil percentage of walking catfish $(P>0.05)$. The percentage at $5^{\text {th }}, 10^{\text {th }}$ and $15^{\text {th }}$ days after feeding treatment ranged from 11.86 to $13.00 \%, 11.67$ to $12.63 \%$ and 10.74 to $14.91 \%$, respectively (Table 8).

Leukocrit

Leucocrit level before treatment ranged from 2.04 to $2.30 \%$. The leucocrit levels at $5^{\text {th }}$, $10^{\text {th }}$ and $15^{\text {th }}$ days post treatment did not change significantly, that were in the range of $1.82-2.39 \%$, $1.83-2.69 \%$ and $1.69-2.60 \%$, respectively (Table 9). Analysis of variance indicated that oral administration of alginate did not affect on leucocrit level $(P>0.05)$.

Table 4. Monocyte percentage of walking catfish before and after feeding with various doses of alginate

\begin{tabular}{lcccc}
\hline \multirow{2}{*}{ Treatment } & \multicolumn{4}{c}{ Day of sampling } \\
\cline { 2 - 5 } & 0 & \multicolumn{4}{c}{5} & 10 & 15 \\
\hline P1 $(0 \mathrm{~g} / \mathrm{kg} \cdot$ Control $)$ & $16.87 \pm 1.29$ & $14.19 \pm 1.54$ & $14.55 \pm 1.31$ & $12.01 \pm 1.40$ \\
P2 $(2 \mathrm{~g} / \mathrm{kg})$ & $15.28 \pm 3.47$ & $16.41 \pm 2.29$ & $16.67 \pm 2.21$ & $11.14 \pm 3.47$ \\
P3 $(4 \mathrm{~g} / \mathrm{kg})$ & $15.57 \pm 4.14$ & $19.20 \pm 2.18$ & $14.98 \pm 2.72$ & $10.63 \pm 2.58$ \\
P4 $(6 \mathrm{~g} / \mathrm{kg})$ & $16.11 \pm 2.65$ & $20.53 \pm 2.86^{*}$ & $12.05 \pm 1.15$ & $10.46 \pm 1.76$ \\
P5 $(8 \mathrm{~g} / \mathrm{kg})$ & $17.99 \pm 0.43$ & $16.66 \pm 2.00$ & $15.52 \pm 2.98$ & $11.16 \pm 1.00$ \\
\hline
\end{tabular}

Asterisk $(*)$ indicates the significant different with control treatment

Table 5. Lymphocyte percentage of walking catfish before and after feeding with various doses of alginate

\begin{tabular}{lcccc}
\hline \multirow{2}{*}{ Treatment } & \multicolumn{4}{c}{ Day of sampling } \\
\cline { 2 - 5 } & 0 & 5 & 10 & 15 \\
\hline P1 $(0 \mathrm{~g} / \mathrm{kg}$. Control $)$ & $54.79 \pm 3.18$ & $53.75 \pm 4.04$ & $52.12 \pm 1.50$ & $60.04 \pm 1.93$ \\
P2 $(2 \mathrm{~g} / \mathrm{kg})$ & $56.08 \pm 4.57$ & $54.20 \pm 3.44$ & $52.99 \pm 3.50$ & $58.23 \pm 2.63$ \\
P3 $(4 \mathrm{~g} / \mathrm{kg})$ & $59.23 \pm 2.13$ & $51.22 \pm 3.00$ & $54.91 \pm 6.46$ & $53.72 \pm 2.04$ \\
P4 $(6 \mathrm{~g} / \mathrm{kg})$ & $56.74 \pm 3.71$ & $51.94 \pm 1.55$ & $54.58 \pm 1.81$ & $59.08 \pm 2.34$ \\
P5 (8 g/kg) & $53.76 \pm 2.31$ & $53.40 \pm 5.29$ & $55.78 \pm 5.19$ & $54.90 \pm 2.42$ \\
\hline
\end{tabular}

Table 6. Trombocyte percentage of walking catfish before and after feeding with various doses of alginate

\begin{tabular}{lcccc}
\hline \multirow{2}{*}{ Treatment } & 0 & 5 & 10 & 15 \\
\cline { 2 - 5 } & $4.24 \pm 0.64$ & $4.00 \pm 0.74$ & $7.27 \pm 2.09$ & $5.26 \pm 0.80$ \\
P1 $(0 \mathrm{~g} / \mathrm{kg}$. Control $)$ & $5.89 \pm 2.24$ & $3.28 \pm 0.62$ & $5.04 \pm 1.67$ & $7.67 \pm 4.17$ \\
P2 $(2 \mathrm{~g} / \mathrm{kg})$ & $3.68 \pm 0.37$ & $3.33 \pm 0.48$ & $6.04 \pm 8.39$ & $7.71 \pm 1.20$ \\
P3 $(4 \mathrm{~g} / \mathrm{kg})$ & $3.90 \pm 1.34$ & $3.14 \pm 0.69$ & $9.43 \pm 5.79$ & $4.69 \pm 1.58$ \\
P4 $(6 \mathrm{~g} / \mathrm{kg})$ & $4.99 \pm 1.13$ & $4.24 \pm 1.46$ & $4.21 \pm 1.12$ & $8.39 \pm 6.72$ \\
P5 $(8 \mathrm{~g} / \mathrm{kg})$ & & & & \\
\hline
\end{tabular}


Table 7. Neutrophil percentage of walking catfish before and after feeding with various doses of alginate

\begin{tabular}{|c|c|c|c|c|}
\hline \multirow{2}{*}{ Treatment } & \multicolumn{4}{|c|}{ Day of sampling } \\
\hline & 0 & 5 & 10 & 15 \\
\hline P1 (0 g/kg . Control) & $13.07 \pm 2.50$ & $13.51 \pm 1.61$ & $13.41 \pm 0.84$ & $11.90 \pm 1.32$ \\
\hline $\mathrm{P} 2(2 \mathrm{~g} / \mathrm{kg})$ & $11.38 \pm 1.23$ & $13.58 \pm 2.29$ & $12.73 \pm 2.57$ & $11.86 \pm 0.61$ \\
\hline P3 $(4 \mathrm{~g} / \mathrm{kg})$ & $12.17 \pm 0.99$ & $13.22 \pm 2.03$ & $12.09 \pm 5.75$ & $14.89 \pm 2.43$ \\
\hline P4 $(6 \mathrm{~g} / \mathrm{kg})$ & $12.45 \pm 0.14$ & $12.07 \pm 1.57$ & $12.05 \pm 1.95$ & $11.78 \pm 2.37$ \\
\hline P5 $(8 \mathrm{~g} / \mathrm{kg})$ & $12.14 \pm 1.36$ & $13.49 \pm 1.95$ & $12.79 \pm 2.16$ & $10.61 \pm 2.75$ \\
\hline
\end{tabular}

Table 8. Eosinophyle percentage of walking catfish before and after feeding with various doses of alginate

\begin{tabular}{lcccc}
\hline \multirow{2}{*}{ Treatment } & \multicolumn{4}{c}{ Day of sampling } \\
\cline { 2 - 5 } & 0 & 5 & 10 & 15 \\
\hline P1 $(0 \mathrm{~g} / \mathrm{kg}$. Control $)$ & $10.62 \pm 3.26$ & $11.86 \pm 2.25$ & $12.63 \pm 2.13$ & $10.74 \pm 1.34$ \\
P2 $(2 \mathrm{~g} / \mathrm{kg})$ & $11.34 \pm 0.56$ & $12.50 \pm 4.34$ & $12.55 \pm 2.67$ & $11.08 \pm 1.89$ \\
P3 $(4 \mathrm{~g} / \mathrm{kg})$ & $9.32 \pm 2.29$ & $13.00 \pm 3.88$ & $11.95 \pm 3.17$ & $13.03 \pm 1.12$ \\
P4 $(6 \mathrm{~g} / \mathrm{kg})$ & $10.77 \pm 2.95$ & $12.26 \pm 3.64$ & $11.87 \pm 1.75$ & $13.97 \pm 5.34$ \\
P5 $(8 \mathrm{~g} / \mathrm{kg})$ & $10.58 \pm 1.24$ & $12.18 \pm 1.37$ & $11.67 \pm 1.00$ & $14.91 \pm 4.82$ \\
\hline
\end{tabular}

Table 9. Leucocrit level of walking catfish before and after feeding with various doses of alginate.

\begin{tabular}{lcccc}
\hline \multirow{2}{*}{ Treatment } & \multicolumn{4}{c}{ Day of sampling } \\
\cline { 2 - 5 } & 0 & 5 & 10 & 15 \\
\hline P1 $(0 \mathrm{~g} / \mathrm{kg}$, Control $)$ & $2.30 \pm 1.71$ & $2.05 \pm 0.99$ & $2.69 \pm 0.23$ & $2.60 \pm 0.31$ \\
P2 $(2 \mathrm{~g} / \mathrm{kg})$ & $2.04 \pm 1.30$ & $2.39 \pm 1.61$ & $2.34 \pm 0.48$ & $2.51 \pm 0.55$ \\
P3 $(4 \mathrm{~g} / \mathrm{kg})$ & $2.08 \pm 0.18$ & $2.28 \pm 0.20$ & $2.26 \pm 0.79$ & $1.69 \pm 1.48$ \\
P4 $(6 \mathrm{~g} / \mathrm{kg})$ & $2.33 \pm 0.44$ & $1.87 \pm 0.13$ & $1.83 \pm 0.53$ & $2.06 \pm 0.05$ \\
P5 $(8 \mathrm{~g} / \mathrm{kg})$ & $2.26 \pm 1.24$ & $1.88 \pm 0.20$ & $2.02 \pm 0.20$ & 1.770 .48 \\
\hline
\end{tabular}

\section{Discussion}

Alginate is found in all species of brown algae (Phaeophyta) as one of the main components of their cell wall. Alginate is composed of two units monomer, namely $\beta$-Dmannuronic acid and $\alpha$-L-guluronic acid. The chemical compositions of alginate vary depending on the species of algae, harvesting time and apart of the algae. For example, alginate containing high guluronic acid can be obtained from the outer cortex of Laminaria hyperborea (Draget et al., 2011).

Alginate is polysaccharide found mainly in brown seaweeds. Fujiki and Yano (1997) have stated that alginate significantly increases survival rate of carp infected with Edwardsiella tarda. The similar results have been demonstrated by Chiu et al. (2008) who reported that alginate improve non-specific immune response and survival rate of tiger grouper challenged with Streptococus sp. and Iridovirus. Although alginate administration have already proved for improvement of the non-specific defense of giant tiger shrimp (Penaeus monodon), carp (Cyprinus carpio) and grouper (Epinephelus sp.), the such effects have not been reported yet in walking cat fish (Clarias sp.).
Anderson and Siwicki (1994) stated that the mechanism of non-specific defense can be evaluated by hematologic observation. Therefore, in this study, the effectiveness of oral administration of alginate for increasing nonspecific defense of walking cat fish have been evaluated through hematologic observation. Parameters observed in this study are Nitroblue Tetrazolium (NBT) activity, phagocytic activity, phagocytic index, leukocyte differentiation, and leucocrit/hematocrit.

Results indicated that NBT activity in blood of walking catfish at $5^{\text {th }}$ day after starting treatment significantly increases by oral administration of alginate. Oral administration of alginate at 4 and $6 \mathrm{~g} / \mathrm{kg}$ of feed significantly improve NBT activity. Alginate at 4 and $6 \mathrm{~g} / \mathrm{kg}$ of feed increase the NBT activity by $49.1 \%$. and $47.7 \%$, respectively. Anderson and Siwicki (1994) have stated that activation of neutrophil and phagocytic cells are able to increase production of radical oxygen indicated by increasing the absorbance in NBT assay approximately $20-30 \%$. Results of this study imply that alginate is potent substance to improve the production of oxygen radical in the blood of walking catfish.

NBT activities at $10^{\text {th }}$ and $15^{\text {th }}$ days are insignificant different comparing to control 
treatment $(P>0.05)$. These results are slightly different with the result reported by Harikrishnan et al. (2010). The authors have reported that alginate at the doses of 1.0 and $2.0 \mathrm{~g} / \mathrm{kg}$ of feed increase NBT activity significantly in grouper at second and fourth weeks during administration. The effectiveness of long term oral administration of immunostimulant has not been determined yet (Sakai, 1998). The effectiveness of oral administration of peptidoglican in rainbow trout is 28 days although the substance is administered for 56 days (Matsuo and Miyazano, 1993). Yoshida et al. (1995) also have reported that oral administration of glucan in catfish increases NBT activity for 30 days, but insignificant effect is observed after 30 days. NBT activity close correlates to phagocytic activity. During the process of phagocytosis, macrophages carry out a massive respiration (respiratory burst) to generate Reactive Oxygen Species (ROS) that are toxic to pathogens. NADPH oxidase also plays an important role in this process to generate superoxide anion $\left(\mathrm{O}_{2}{ }^{-}\right)$ which will be converted into hydrogen peroxide $\left(\mathrm{H}_{2} \mathrm{O}_{2}\right)$. This peroxide is toxic to bacteria (Castro et al., 2003).

Phagocytic activity (PA) is the ability of phagocytic cells to destroy pathogens that invade to non-specific immune system. Results indicated that oral administration of alginate significantly increases the phagocytic activity at $5^{\text {th }}$ day of feeding regime. Alginate at a dose of $4 \mathrm{~g} / \mathrm{kg}$ of feed significantly increases phagocytic activity by $29.1 \%$ comparing to the controls treatment. Cells responsible in PA are mononuclear cells (monocytes and macrophages), and polymorphonuclear cells or granulocytes (Baratawidjaya, 2002). According to Ale et al. (2011), activation of macrophages by polysaccharide is mediated by the presence of specific membrane receptors on macrophages. Receptors such as Toll-Like Receptor 4 (TLR-4), Cluster of Differentiation-14 (CD-14), Competent Receptor-3 (CR - 3) and Scavenging Receptor (SR) are able to recognize polysaccharide compounds including alginate. Cheng and $\mathrm{Yu}$ (2012) reported that the addition of alginate at concentrations of 1,2 , and $3 \mathrm{~g} / \mathrm{kg}$ of feed increase the phagocytic activity of abalone for 14 days.

Although the oral administration of alginate increases significantly the phagocytic activity, but such effect was not observed on phagocytic index. The phagocytic index can be used as a parameter of the improvement of the immune system by increasing the function of cells phagocytes (Baratawidjaja, 2002). Phagocytosis index may be influenced by complement which has a function as a stimulator of phagocytes cells to migrate toward the site of infection. In addition, complement also has a function either to increase the frequency of antigen-antibody complexes or to attach to the receptor of phagocytes cells (Irianto, 2005).

Leukocyte differentiation has been evaluated by observing monocytes, lymphocytes, trombocyte, neutrophils and eosinophils. Fujaya (2004) has stated that the fish leukocytes consists of eosinophil, granulocytes, neutrophil, granulocytes, lymphocytes, monocytes and trombocyte. Oral administration of alginate at $6 \mathrm{~g} / \mathrm{kg}$ of feed increases significantly the percentage of monocyte at $5^{\text {th }}$ day post treatment. Monocyte cells are oval or round with a larger size than other types of leukocytes, and have oval-shaped nucleus located at the cell edge. Monocytes will develop into macrophages and be able to ingest more particle than monocytes (Baratawidjaya, 2002). According Irianto (2005), monocytes and macrophages attach and ingest antigen mediated by a variety of surface membrane receptors. In this study, the others type of leukocyte rather than monocyte are insignificantly affected by oral administration of alginate. Health status of fish can also be evaluated by observing hematocrit and leukocrit. Anderson and Siwicki (1994) stated that the leukokrit level is a better indicator for evaluating fish health status than haematocrit. Oral administration of alginate has insignificant effect on leukokrit of walking catfish.

In summary, oral administration of alginate at $4 \mathrm{~g} / \mathrm{kg}$ of feed increases NBT and phagocytic activities at $5^{\text {th }}$ day after treatment. At a higher concentration, $6 \mathrm{~g} / \mathrm{kg}$ of feed, alginate increases the percentage of monocytes and NBT activity. The effect of oral administration of alginate on non-specific immune response is not determined at $10^{\text {th }}$ and $15^{\text {th }}$ day. The effectiveness of immunostimulant administration is influenced by several factors such as the nature of immunostimulant, administration method, time period of administration and the dose. Sakai (1998) has stated that the immunostimulant administration in the long term is not inevitably effective. The period of oral administration of alginate in walking catfish should be further investigated 


\section{Conclusion}

Oral administration of alginate in walking catfish at $4 \mathrm{~g} / \mathrm{kg}$ of feed increases NBT and phagocytic activities significantly $(P<0.05)$ in 5 days. The higher dose of alginate at $6 \mathrm{~g} / \mathrm{kg}$ of feed increases NBT activity and monocyte percentage significantly $(P<0.05)$ in the same period of feeding trial.

\section{References}

Anderson, D.P. and A.K. Siwicki. 1994. Symplified Assay for Measuring Nonspesifik Defence Mechanism in Fish. Fish Health Section/American Fisheries Meeting. Seatle. Washington, p. 1-26.

Ale, M.T., J.D. Mikkelsen, and A.S. Meyer. 2011. Important determinant for fucoidan bioactivity: a critical review of structure-function relations and extraction methods for fucose-containing sulfated polysaccharides from brown seaweeds. Marine Drugs, 9: 2106-2130.

Baratawidjaya, K.G. 2002. Imunologi Dasar. Balai Penerbit Fakultas Kedokteran Universitas Indonesia. Jakarta. hlm. 3-69.

Castro, R., I. Zarra, and J. Lamas. 2003. Watersoluble seaweed extracts modulate the respiratory burst activity of turbot phagocytes. Aquaculture, 229: 67-78.

Cheng, W. and J.S. Yu. 2012. Effects of the dietary administration of sodium alginate on the immune responses and disease resistance of Taiwan abalone. Haliotis diversicolor supertexta. Fish \& Shellfish Immunology, 34 902-908.

Chiu, S.T., R.T. Tsai, J.P. Hsu, C.H. Liu, and W. Cheng. 2008. Dietary sodium alginate administration to enhance the non-specific immune responses. and disease resistance of the juvenile grouper Epinephelus fuscoguttatus. Aquaculture, 277: 66-72.

Draget, K.I., S.T. Moe, G.S. Bræk, and O. Smidsrød. 2011. Alginates. In : Stephen . A.
M.. G.O. Phillips and P.A. Williams. 2006. Food Polysaccharides and Their Applications. Second Edition. Taylor and Francis Group, USA. p. 290-328.

Fujaya, Y. 2004. Fisiologi Ikan. Dasar Pengembangan Teknik Perikanan. Rineka Cipta. Jakarta.

Fujiki, K. and T. Yano. 1997. Effects of sodium alginate on the non-specific defence system of the common carp (Cyprinus carpio L.). Fish and Shellfish Immunology, 7: 417-427.

Harikrishnan, R., M.C. Kim, J.S. Kim, Y.J. Han, I.S. Jang, C. Balasundaram, and M.S. Heo. 2010. Immunomodulatory effect of sodium alginate enriched diet in kelp grouper Epinephelus brneus against Streptococcus iniae. Fish and Shellfish Immunology, 30: 543-549.

Irianto, A. 2005. Patologi Ikan Teleostei. Gadjah Mada University Press. Yogyakarta. hlm. 83-94.

Isnansetyo, A. 2006. Petunjuk Praktikum Evaluasi Pertahanan Non Spesifik Ikan. Universitas Gadjah Mada. Yogyakarta.

Matsuo, K. and I. Miyazano. 1993. The influence of long term administration of pedtidoglucan on the chanel catfish. In: Sakai. M. 1998. Current research status of fish immunostimulant. Aquaculture, 172 : 63-92.

Rachmat, R. 1999. Potensi alga coklat di indonesia dan prospek pemanfaatannya. Prosiding Pra Kipnas VII Forum Komunikasi Ikatan Fikologi Indonesia, 31-35.

Sakai, M. 1998. Current research status of fish immunostimulant. Aquaculture, 172 : 63-92

Yeh, S.T., C.S. Lee, and J.C. Chen. 2005. Administration of hot water extract of brown seaweed Sargassum duplicatum via immersion and injection enhances the immune resistance of white shrimp Litopenaeus vannamei. Fish and Shellfish Immunology, 20: 332-345.

Yoshida, T., R. Kruger, and V. Inglis. 1995. Augmentation of non-specific protection in asian catfish. Clarias gariepinus (Burchell). by the long term administration of immunostimulants. In: Sakai. M. 1998. Current research status of fish immunostimulant. Aquaculture, 172 : 63-92. 